http://jmscr.igmpublication.org/home/ ISSN (e)-2347-176x ISSN (p) 2455-0450 crossref DOI: https://dx.doi.org/10.18535/jmscr/v9i2.21

\title{
Determination of Bacterial Quality of Water in Randomly Selected Swimming Pools in Port Harcourt and Obio-Akpo Local Government Areas, Rivers State, Nigeria
}

Authors

Constancy Prisca Aleru, Vivian Nkemkanma Agi, Joy Lawson-Ndu, Queen Nene Eme Department of Medical Laboratory Science, Rivers State University, Nkpolu-Oroworukwo, Port Harcourt,

Nigeria

Corresponding Author

Constancy Prisca Aleru

\begin{abstract}
This study provides a survey of bacterial quality of swimming pools water in Port Harcourt and Obio-Akpo Local Government Areas (LGA) of Rivers State, Nigeria. A total number of twenty (20) outdoor swimming pools were examined for bacterial quality. Of the 20 swimming pools, $11(1,3,4,5,7,8,10,13,14,19$ and 20) had bacteria. Swimming pools 1, 3, 4, 5, 7, 8, 10, 13, 14, 19 and 20 had the following bacterial isolates: 6(5.83\%), 4(3.88\%), 20(19.42\%), 5(4.85\%), 18(17.48\%), 15(14.56\%), 17(16.50\%), 9(8.74 $\%), 2(1.94 \%), 5(4.85 \%)$ and $2(1.94 \%)$, respectively. Out of the 103 isolates of bacteria identified in this study, 63(61\%) were coagulase negative Staphylococcus species, 11(10.68\%) were Bacillus cereus, 11(10.68\%) were Micrococcus species, 10(9.71\%) were Staphylococcus aureus and 8(7.77 \%) were Pseudomonas aeruginosa.Among the swimming pools that had bacteria, swimming pools 8, 13 and 20 did not have Staphylococcus aureus, whilst swimming pools 3, 5, 8, 10, 13 and 20 had Micrococcus species. According to World Health Organisation's standard for recreational water, the absence of coliforms and faecal coliforms, such as Escherichia coli, showed that the 20 swimming pools used for this study are considered to be within the acceptable limits for certifying microbiological water quality. Although, there may still be need for care and maintenance of the swimming pools.
\end{abstract}

\section{Introduction}

Worldwide, swimming pools are used for recreational activities, sports and rehabilitative treatments $^{[1,2]}$. In Nigeria, people take their first step in learning how to swim at swimming pools, as it is safer and more convenient than going to the river. The use of swimming pools is more popular than it used to bein the past and if the maintenance of the pools is poor, microorganisms could be found there. These microorganisms, which could be introduced into the pools are bacteria, fungi, protozoa or viruses. Because of the activities of some bathers, such as passing excreta during swimming, there could be risks of infections. According to reports, aside from faecal contamination of swimming pools by bathers, swimming pools may also be contaminated due to direct animal contamination from birds and rodents ${ }^{[2,3]}$. Actually, the passing of excreta into swimming pools may not be deliberate, as some of the bathers may have diarrhoea. It has also been noted that swimming pools could be contaminated 
through non-faecal human shedding, such as saliva, vomit, skin and mucus. These non-faecal human shedding could also be potential sources of pathogenic microorganisms ${ }^{[3,4]}$.

Some researchers have isolated bacteria from swimming pools. These bacteria included Escherichia coli(E. coli) and other pathogenic bacteria, such as Pseudomonas aeruginosa, Staphylococcus aureus, Proteus vulgari, Clostridium perfringens, Staphylococcus epidermidis and Enterococcus faecalis ${ }^{[2,5]}$. According to the researchers, the presence of $E$. coli and other coliforms showed that the pools they worked on did not meet the World Health Organisation (WHO) standard for recreational water. Staphylococcus aureus may also be present in swimming pools without the presence of coliforms, including faecal coliforms ${ }^{[6]}$. For instance, some researchers have reported that the major contaminating bacteria of swimming pools are Staphylococcus aureus and Staphylococcus epidermidis ${ }^{[7,8]}$. It has also been noted that Pseudomonas aeruginosa is frequently the bacterium isolated from the ears of swimmers with Otitis media ${ }^{[9]}$.

Research reports have also shown that cases of infectious diseases are as a result of accidentally swallowing pool water contaminated with microorganisms. Microorganisms associated with eye, skin, ear and gastrointestinal tract infections were the ones reported to be mostly transmitted by recreational water, such as swimming pools $^{[10,11,12]}$. In 1977, an outbreak of conjunctivitis in the USA was linked to summercamping and it was observed that the chances of contracting the illness increases by $50 \%$ amongst the same users of the pools when compared to non-users ${ }^{[13]}$.

It is unfortunate that some of those who take care of swimming pools may have little or no knowledge about the importance of swimming pool maintenance, in order to meet both the physicochemical and microbiological standards. Some of them may not know how to use the chemicals (chlorine) used to sanitise the swimming pools and as a result, less or more is added in the pools. Some researchers have noted that under application of chlorine help microorganisms thrive in the water, while over application may lead to toxic effects on swimmers ${ }^{[14,15]}$. In this present study, we determined the quality of water in twenty randomly selected swimming pools in Port Harcourt and Obio-Akpo Local Government Areas, Rivers State, Nigeria

\section{Materials and Methods}

\subsection{Study Area}

This study was carried out in Port Harcourt and Obio-Akpo Local Government Areas (LGAs) of Rivers State, Nigeria. These LGAs are made up of more than 1 million people and they have a common boundary. The City of Rivers State is Port Harcourt and as a result, people with different ethnic groups reside there; this has increased the social life of the residents.

Foreign nationals work and live in Rivers State, as the State is rich in oil and gas; most of the oil and allied industries are in Port Harcourt. The City of Port Harcourt has many hotels and recreational centres. These hotels and recreational centres, as well as club houses have swimming pools, which are used for recreational purposes.

\subsection{Description of Swimming Pools}

Twenty (20) swimming pools were used for this study and they were located in hotel and recreational premises. Subsequently, they would be referred to by numbers (number 1 to 20 ) as the owners of the pools did not want the names of their hotels and recreational centres displayed.The shapes of the pools were different; some of them were circular, while others were rectangular. The sizes ranged from $50 \mathrm{~m}$ to $1500 \mathrm{~m}$. The swimming pools were made of glazed tiles and had flowthrough of 2.2 to $2.85 \mathrm{~m}$ deep.

\subsection{Sample Collection}

The samples were collected each into a sterile 250 $\mathrm{ml}$ wide mouth plastic container at depth of about $30 \mathrm{~cm}$ from different parts of each of the swimming pools. The samples were collected every morning before bath and in the evenings. 
After sample collection, the samples were taken to the Medical Microbiology Laboratory in Medical Laboratory Science Department, Rivers State University, Port Harcourt, Nigeria, for immediate bacteriological analysis.

\subsection{Preparation of Bacterial Media}

Bacteriological media were prepared and sterilised according to the manufacturers' instructions. Standard plate count agar, McConkey agar and Nutrient agar were prepared and sterilised by autoclaving at $121{ }^{\circ} \mathrm{C}$ for 15 minutes. The sterilised media were poured aseptically into petri dishes and allowed to solidify. Then, they were stored in the refrigerator at $4{ }^{\circ} \mathrm{C}$ for subsequent use. The bacteriological media used were products of Oxoid UK.

\subsection{Bacteriological Examination of Samples}

Samples were serially diluted and plated by spread plate method using standard plate count agar [16].The estimation of total coliform and faecal coliform counts were carried out on McConkey agar plates [17]. The samples were plated within 2 hours from the time of sample collection and incubated at $37{ }^{\circ} \mathrm{C}$ for $24-48$ hours.

\subsection{Identification of Isolated Bacteria}

The characterisation and identification of bacteria were carried out using the procedures by[18,19].Gram staining reaction, catalase, motility, coagulase, citrate utilisation, oxidase reaction, urease and sugar fermentation were the chemical and biochemical tests employed.

\section{Results}

Of the twenty (20) swimming pools used for this study, 11 had bacteria. The swimming pools that had bacterial isolates were pools $1,3,4,5,7,8$, $10,13,14,19$ and 20 , with the percentages of 6(5.83\%), 4(3.88\%), 20(19.42\%), 5(4.85\%), 18(17.48\%), 15(14.56\%), 17(16.50\%), 9(8.74 $\%), 2(1.94 \%), 5(4.85 \%)$ and $2(1.94 \%)$, respectively (Figure 1).

As shown in Figure 2, coagulase negative Staphylococcus species $(61 \%)$ had the highest percentage of bacteria isolated from the swimming pools. On the other hand, Staphylococcus aureus (9.71\%) and Pseudomonas aeruginosa (7.77 \%) had the least percentage.

Coagulase negative Staphylococcus species were the most frequently occurring bacteria, as they were isolated from $11(1,3,4,5,7,8,10,13,14$, 19 and 20) swimming pools. However, 8swimming pools (1, 3, 4, 5, 7,10, 14 and 19) had Staphylococcus aureus and only 4 swimming pools had Micrococcus species (3, 4, 8, 10 and 13) and Pseudomonas aeruginosa(1, 5, 8 and 10). According to the results, all the bacteria isolated in this study were found in swimming pool 10 (Figure 3).

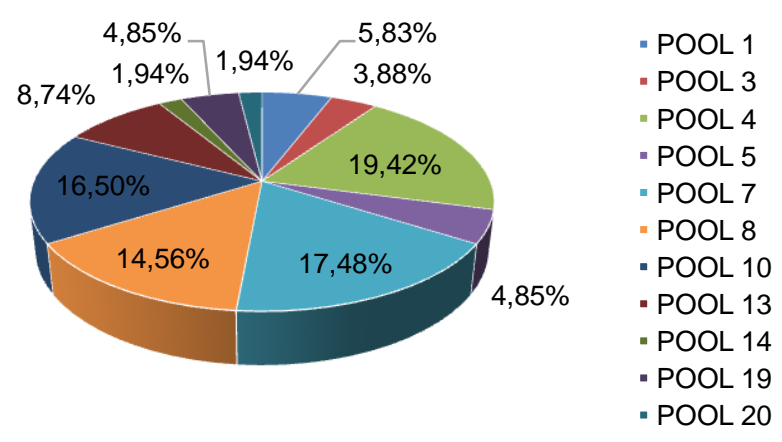

Figure 1: Percentages of total heterotrophic bacterial count from the eleven (11) positive swimming pools. 


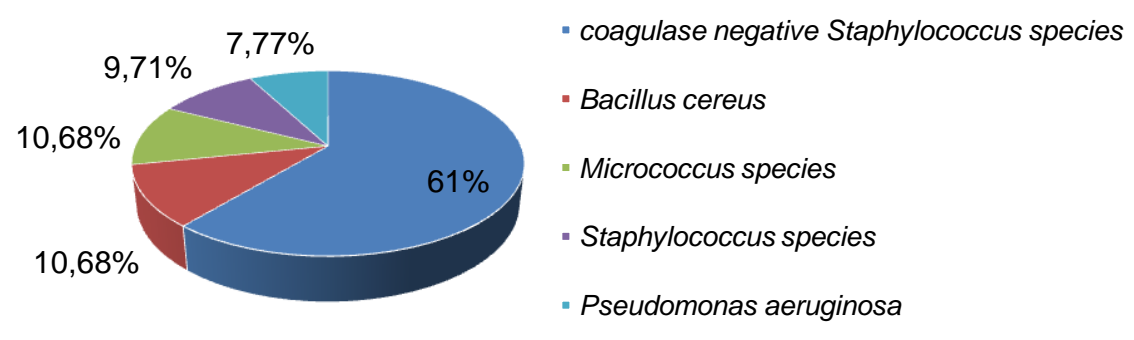

Figure 2: The percentage occurrences of bacteria isolated from the swimming pools

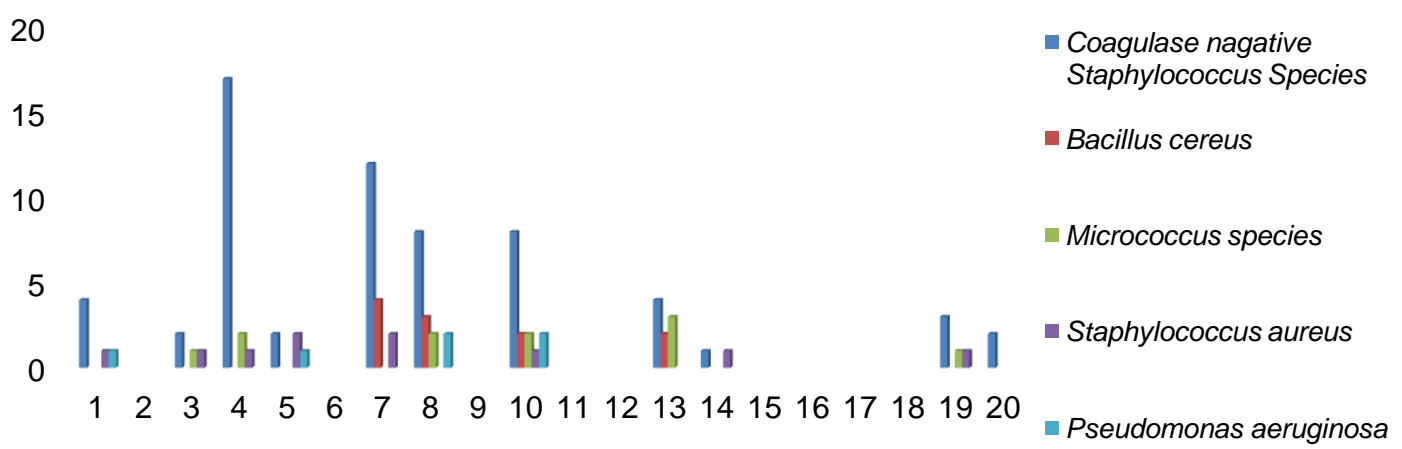

Figure 3: The frequency occurrences of isolated bacteria from each swimming pool

\section{Discussion}

This study revealed that out of 20 swimming pools used study, 11 had bacteria. Swimming pools $1,3,4,5,7,8,10,13,14,19$ and 20 had bacterial isolates as follows: $6(5.83 \%), 4(3.88 \%)$, $20(19.42 \%), 5(4.85 \%), 18(17.48 \%), 15(14.56$ $\%), 17(16.50 \%), 9(8.74 \%), 2(1.94 \%), 5(4.85 \%)$ and $2(1.94 \%)$, respectively. Of the 103 isolates of bacteria identified in this study, 63(61\%) were coagulase negative Staphylococcus species, 11(10.68\%) were Bacillus cereus, 11(10.68\%) were Micrococcus species, 10(9.71\%) were Staphylococcus aureus and 8(7.77 \%) were Pseudomonas aeruginosa. Swimming pools 8, 13 and 20 did not have Staphylococcus aureus, while swimming pools 3, 5, 8, 10, 13 and 20 had Micrococcus species. The results of this study is similar to the works of other researchers who carried their research in countries order than Nigeria. For instance, In Greece, ${ }^{[20]}$ isolated Staphylococcus epidermides, Klebsiella, Pseudomonas, Enterobacter, Leuconostoc and Staphylococcus aureus ${ }^{[20]}$. Another example is a research carried out in Ghana. The researchers isolated Klebsiella pneumonae, Staphylococcus epidermides, Enterobacter faecalis, Staphylococcus aereus and E. coli ${ }^{[21]}$.

Furthermore, in other parts of Nigeria, related studies on swimming pools have been carried out and different species of bacteria were isolated. In $2010,{ }^{[22]}$ carried out a study on swimming pools in Ilorin, Nigeira and they isolated the following bacteria: Lactobacillus, Bacillus, Citrobacter, Corynobacterium, Micrococcus, Aeromonas, Staphylococcus aureu, Pseudomonas, E. coli and Klebsiella. In Lagos Nigeria, a similar study has 
as well been carried out. In this study, Staphylococcus epidermidis, Bacillus cereus, E. coli, Pseudomonas aeruginosa, Enterococcus faecalis, Proteus vulgaris, Staphylococcus aureus and Clostridium perfringes were isolated ${ }^{[5]}$.

The most prevalent bacteria isolated in this study were the species of Staphylococcus (coagulase negative Staphylococcus species). This report is not in conformity with the findings of ${ }^{[8,23]}$ who reported that approximately $40 \%$ of the microorganisms isolated from swimming pools they worked on, were Bacillus species. Staphylococcus epidermidis exists on human skin as normal flora; this may be the reason coagulase negative Staphylococcus species were more in this current study than other species of bacteria. Although, coagulase negative Staphylococcus species are not always implicated in infectious diseases, they could cause severe infections in humans ${ }^{[7,24,25]}$. In immune-compromised patients, Staphylococcus epidermidis has been reported to cause severe infections ${ }^{[25]}$. Moreover, Pseudomonas aeruginosa has been reported to be associated with Otitis media in swimmers ${ }^{[4,26]}$.

Another study revealed that Staphylococcus aureus was the most predominant bacterium found to contaminate swimming pool water ${ }^{[8]}$. It has been noted that Bacillus species and Staphylococcus aureus produce enterotoxins and that they could be associated with gastroenteritis when ingested with swimming pool water ${ }^{[5,27]}$. In spite of the fact that owners of swimming pools have recirculating system that filter and disinfect their swimming pools, relevant studies have shown that pools are not completely free from microorganisms ${ }^{[28,29]}$. However, the absence of coliforms or faecal coliforms, such as Escherichia coli, as revealed in this study shows that some of the swimming pool owners in Port Harcourt and Obio-Akpo Local Government Areas (LGAs) of Rivers State complied with standard for recreational waters ${ }^{[30]}$. Nonetheless, swimming pools in these LGAs and in other parts of Nigeria should be adequately and frequently monitored and maintained to ensure they satisfy the recreational needs for the people.

\section{Conclusion}

Even if the swimming pools met the World Health Organisation standard (WHO) for recreational water of zero coliform and faecal coliform, such as $E$. coli, there is still need to educate staff and users of swimming pools to avoid public health hazard. Properly training swimming pool workers is very essential, and pools should be sanitized routinely. It is also important to monitor for potential microbial hazards, which is done using indicator microorganisms. This is to control water quality and prevent the transmission of infectious diseases in the swimming pools.

\section{References}

1. Al-Kkhatib IA, Salah S. Bacteriological and chemical quality of swimming pools water in developing countries: A case study in the West Bank of Palestine. Int. J. Environ. Health Res. 2003;13(1):17-22.

2. Amala SE,Aleru CP. Bacteriological quality of swimming pools water in Port Harcourt Methropolis. Natural Science. 2016; 8:79-84.

3. World Health Organisation (WHO). Microbial Hazards. In: Guidelines for Safe Recreational Water Environments. Swimming Pools and Similar Environment, Volume 2, WHO Press, Geneva, 26-59 (Chapter 3); 2006.

4. Ezeet VC, Onwuakor CE, Ikwuegbu AL. Microbiological and Physicochemical Characteristics of Swimming Pool Water in Owerri, Imo State, Nigeria. Journal of Applied and Environmental Microbiology. 2015; 3:6-10.

5. Bello OO, Mabekoje OS, Egberongbe HO, Bello TK. Microbial Qualities of Swimming Pools in Lagos, Nigeria. International Journal of Applied Science and Technology. 2012;2:89-96. 
6. Mates A, Schaffer M. A Simple Method for Counting Staphylococcus aureus in Swimming Pool Water. Micriobios. 1986;46:45-49.

7. Klapes NA, Vesley D. Rapid Assay for in Situ Identification of Coagulase-Positive Staphylococci Recovered by Membrane Filtration from Swimming Pool Water. Applied and Environmental Microbiology. 1986; 52:589-590.

8. Ita AY,Ekpombok MU. Pollution Status of Swimming Pools in South-South Zone of South-Eastern Nigeria Using Microbiological and Physicochemical Indices. Southeast Asian Journal of Tropical Medicine and Public Health. 2004; 35:488-493.

9. Alock SR. Acute Otitis Externa in Divers Working in the North Sea. A Microbiological Survey of Seven Saturated Divers. Journal of Hygiene. 1977; 18:359409.

10. Centre for Disease Control and Prevention (CDC). Pseudo Monastery Dermatitis/ Folliculitis Associated with Pools and Hot Tubes-Colorado and Marine, 1999-2000. MMWR. 2000; 49:1087-1091.

11. Wade TJ, Pai N, Eisenberg JNS, Colford JM. Do U.S. EPA Water Quality Guidelines Recreational Waters Prevent Gastrointestinal Illness? A Systematic Review and Meta-Analysis. Environmental Health Perspective.2003;111:1102-1109. http://dx.doi.org/10.1289/ehp.6241

12. Kiyohara N, Kibayakawa YL, Lyman H, Osafune I. Identification of Bacterial Flora in the Water of Swimming Pools throughout the Year. Japan Journal of Physical Education Health and Sports Sciences. 2010; 51:1-9. http://dx.doi.org/10.5432/jjpehss.51.1

13. Alice LS. Principles of Microbiology. 5th Edition, CV Mosby, London. 1977; 661710.
14. Martinez TT, Long C. Explosion risk from swimming pool chlorinators and review of chlorine toxicity. Clin. Toxicol.1995; 33:349-354.

15. Bernard AS, Carbonnelle O, Michel SH, de Burbure $\mathrm{C}$, et al. Lung hyperpermeability and asthma prevalence in school children: Unexpected associations with the attendance at indoor chlorinated swimming pools Occup. Environ. Med. 2003; 60:385-394.

16. Harrigan MG, McCane ME. Laboratory Methods in Food and Diary Microbiology. Academic Press, London. 1976.

17. Oxoid.Oxoid Manual of Dehydrated Culture Media, Ingredients and Other Laboratory Services. Oxfoid, Basingstoke.1985.

18. Cowan and Steel (1985). Manual for the Identification of Bacteria. Barrow GI, Feltham RKA. (Eds.).Cambridge University Press, Cambridge.

19. Holt JG, Krieg NR, Seath PHA, Satley JT, Williams ST. Bergey's Manual of Determinative Bacteriology. $9^{\text {th }}$ Edition, Williams and Wilkins, Baltimore, 804. 1994.

20. Chrissanthy P, Vangelis E, Hercules S, Panagiota G, Giannakppoulos X, Catherine D, George F, Helen G, Panagiotis K, Stamatina L. Microbiological Quality of Indoor and Outdoor Swimming Pools in Greece: Investigation of Antibiotic Resistance of the Bacterial Isolates. International Journal of Hygiene and Environmental Health. 2008; 211:385-397. http://dx.doi.org/10.1016/j.ijheh.2007.06.0 07

21. George O, Simon KS, Emmanuel L, Emmanuel T. Bacteriological Quality Assessment of Swimming Pools in OsuLabadi Area, Accra. Journal of Natural Science Research. 2014;4:126-129. 
22. Sule IO, Agbabiaka TO, Saliu BK, Oyerinde EO. Physicochemical and Bacteriological Assessment of Some Swimming Pools within Ilorin Metropolis, Kwara, Nigeria. Best Journal. 2010; 7:108112.

23. Shittu OB, Olaitan JO,Amusa TS. Physicochemical and Bacteriological Analyses of Water Used for Drinking and Swimming Purposes in Abeokuta, Nigeria. African Journal of Biomedical Research. 2008; 11:285-290.

24. Sumerville DA. The Normal Flora of the Skin in Different Age Group. British Journal of Dermatology. 1969; 81:248258. http://dx.doi.org/10.1111/j.13652133.1969.tb13976.x

25. Ramzi MH, John ME. What to Do with Coagulate-Negative Staphylococci. The Canadian Journal of CME. 2007; 19-20.

26. World Health Organisation (WHO). Guidelines for Drinking Water Quality, Volume 1: Recommendations. 3rd Edition, WHO, Geneva.2004.

27. Prescott LM, Harley JP, Klein OA. Human Disease Caused by Bacteria. In: Prescott, L.M., Harley, J.P. and Klein, O.A., Eds., Microbiology, 5th Edition, McGraw-Hill Publisher, New York. 2002: 732-735.

28. Fiorillo L, Zucker M, Sawyer D, Lin AN. The Pseudomonas Hot-Foot Syndrome. The New England Journal of Medicine. 2001; 345:335-338. http://dx.doi.org/10.1056/NEJM20010802 3450504

29. Barben T, Hafen G, Schmid J. Pseudomonas aeruginosa in Public Swimming Pools and Bathroom Water of Patients with Cystic Fibrosis. Journal of Cystic Fibrosis. 2005;4:227-231. http://dx.doi.org/10.1016/j.jcf.2005.06.003
30. World Health Organisation (WHO). Guidelines for Safe Recreational Water Environments, Vol. 1, Coastal and Fresh Waters. WHO, Geneva.2003. 